\title{
STRENGTH PROPERTIES OF BAGASSE ASH AND GGBS BASED GEO-POLYMER CONCRETE
}

\author{
P Abhilash \\ Annamacharya Institute of Technology, Tirupati, Andhra Pradesh, India
}

\begin{abstract}
The second most consumed product in the world is Cement. It contributes nearly $7 \%$ of the global carbon dioxide emission. Geo-polymer concrete (GPC) is a special type of concrete that is manufactured using industrial waste like baggase ash, GGBS which are considered as a more eco-friendly alternative to Ordinary Portland Cement $(O P C)$ based concrete. By using this type of industrial by-products in concrete industry as a replacement for cement we can reduce the usage of cement which results in minimizing the emission of green houses gases into the atmosphere and also savings in cost. This project mainly aims at the study of effect of Bagasse ash (BA) and ground granulated blast furnace slag $(G G B S)$ on the mechanical properties of geo polymer concrete $(G P C)$ when they were replaced for cement at different replacement levels (BA50-GGBS50,BA75-GGBS25, BA100-GGBSO) using Sodium silicate (Na2SiO3) and sodium hydroxide $(\mathrm{NaOH})$ solutions as alkaline activators. Specimens were casted and cured for different curing periods like 7, 14, 28, 56 and 112 days at ambient room temperature to determine the mechanical properties of geo-polymer concrete. Test results shows that as the percentage of GGBS in the mix is increasing, mechanical properties such as compressive strength, split tensile strength and flexural strength were increasing.
\end{abstract}

Keywords: Geopolymer concrete, GGBS, Bagasse ash, Sodium silicate, Sodium hydroxide, Compressive strength, Split tensile strength, Flexure strength

Cite this Article: P Abhilash, Strength Properties of Bagasse Ash and GGBS Based Geo-Polymer Concrete, International Journal of Civil Engineering and Technology, 11(6), 2020, pp. 103-110.

https://iaeme.com/Home/issue/IJCIET?Volume $=11 \&$ Issue $=6$

\section{INTRODUCTION}

Concrete is the most widely used construction material in the world and Ordinary Portland Cement (OPC) is the major ingredient used in concrete. The production of cement releases large amount of carbon dioxide $\left(\mathrm{CO}_{2}\right)$ to the atmosphere that significantly contributes to greenhouse gas emissions. It is estimated that one ton of $\mathrm{CO}_{2}$ is released into the atmosphere for every ton of OPC produced ${ }^{1}$. In view of this, there is a need to develop sustainable alternatives to conventional cement utilizing the cementitious properties of industrial byproducts such as Bagasse ash and ground granulated blast furnace $\operatorname{slag}^{2-4}$. On the other side, the abundance and availability of Bagasse ash and GGBS worldwide create opportunity to 
utilize these by-products, as partial replacement or as performance enhancer for OPC. In 1978, Davidovits developed a binder called geo-polymer to describe an alternative cementitious material which has ceramic-like properties. Geo-polymer technology is one of the new technologies attempted to reduce the use of Portland cement in concrete. Geopolymer are environmental friendly materials that do not emit green house gases during polymerization process. Geopolymer can be produced by combining a pozzolanic compound or aluminosilicate source material with highly alkaline solutions ${ }^{5}$. Geopolymers are made from source materials with silicon $(\mathrm{Si})$ and Aluminium ( $\mathrm{Al}$ ) content and thus cement can be completely replaced by marginal materials such as Bagasse ash and ground granulated blast furnace slag which is rich in silica and alumina ${ }^{6-7}$. Bagasse ash and GGBS reacts with alkaline solutions to form a cementitious material which does not emit carbon dioxide into the atmosphere and enhances the mechanical properties of the geo-polymer concrete. Davidovits (1978) proposed that binders could also be produced by polymeric reaction of alkaline liquids with the silicon and the aluminum in source materials or by-product materials such as Bagasse ash and rice husk ash. Portland cement is still the main binder in concrete construction prompting a search for more eco-friendly materials. Furthermore, it has been reported that the durability of ordinary Portland cement concrete is under examination, as many concrete structures especially those built in corrosive environments start to deteriorate after 20 to 30 years, even though they have been designed for more than 50 years of service life.

\section{EXPERIMENTAL STUDY}

\subsection{Experimental Program}

Our objective was to determine the effect of GGBS and Fly-ash on the mechanical properties of geo polymer concrete. In this respect, GGBS and Fly-ash were used as binders, Sodium hydroxide and Sodium silicate were used as alkaline activators, Crushed granite stones of size $20 \mathrm{~mm}$ and $10 \mathrm{~mm}$ of coarse aggregate are used, river sand is used as fine aggregate.

\subsection{Material Properties}

\subsubsection{Binders}

Bagasse ash and GGBS were used as binders in geo polymer concrete and their physical and chemical properties of the Ground Granulated Blast Furnace Slag were tabulated below

Table 1 Chemical and Physical Properties of Bagasse Ash and GGBS

\begin{tabular}{|l|c|c|}
\hline \multicolumn{1}{|c|}{ Particulars } & BAGASSE ASH & GGBS \\
\hline Chemical composition & & 30.61 \\
\hline \% Silica $\left(\mathrm{SiO}_{2}\right)$ & 65.6 & 16.24 \\
\hline \% Alumina $\left(\mathrm{Al}_{2} \mathrm{O}_{3}\right)$ & 28.0 & 0.584 \\
\hline \% Iron Oxide $\left(\mathrm{Fe}_{2} \mathrm{O}_{3}\right)$ & 3.0 & 34.48 \\
\hline \% Lime $(\mathrm{CaO})$ & 1.0 & 6.79 \\
\hline \% Magnesia $(\mathrm{MgO})$ & 1.0 & - \\
\hline \% Titanium Oxide $\left(\mathrm{TiO}_{2}\right)$ & 0.5 & 1.85 \\
\hline \% Sulphur Trioxide $\left(\mathrm{SO}_{3}\right)$ & 0.2 & 2.1 \\
\hline Loss on Ignition & 0.29 & 2.86 \\
\hline Physical properties & & 400 \\
\hline Specific gravity & 2.24 & \\
\hline Fineness $\left(\mathrm{m}^{2} / \mathrm{Kg}\right)$ & 360 & \\
\hline
\end{tabular}




\subsubsection{Alkaline Liquids}

The alkaline liquid used was a combination of sodium silicate solution and sodium hydroxide solution. The sodium silicate solution $\left(\mathrm{Na}_{2} \mathrm{O}=13.7 \%, \mathrm{SiO}_{2}=29.4 \%\right.$, and water $=55.9 \%$ by mass) was purchased from a local supplier. The sodium hydroxide $(\mathrm{NaOH})$ in flakes or pellets from with $97 \%-98 \%$ purity was also purchased from a local supplier. The sodium hydroxide $(\mathrm{NaOH})$ solution was prepared by dissolving either the flakes or the pellets in required quantity of water. The mass of $\mathrm{NaOH}$ solids in a solution varied depending on the concentration of the solution expressed in terms of molarity, $\mathrm{M}$. For instance, $\mathrm{NaOH}$ solution with a concentration of $10 \mathrm{M}$ consisted of $10 \times 40=400$ grams of $\mathrm{NaOH}$ solids (in flake or pellet form) per litre of the solution, where, 40 is the molecular weight of sodium hydroxide $(\mathrm{NaOH})$ pellets or flakes.

\subsubsection{Coarse Aggregate}

Crushed granite stones of size $20 \mathrm{~mm}$ and $10 \mathrm{~mm}$ of coarse aggregate are used. The bulk specific gravity in oven dry condition and water absorption of the coarse aggregate $20 \mathrm{~mm}$ and $10 \mathrm{~mm}$ as per IS code were 2.58 and $0.3 \%$ respectively. The gradation of the coarse aggregate was determined by sieve analysis as per IS code and presented in the Tables 2 and 3.

Table 2 Sieve analysis of $20 \mathrm{~mm}$ Coarse aggregate

\begin{tabular}{|c|c|c|c|c|c|c|}
\hline S.No & $\begin{array}{c}\text { Sieve } \\
\text { size } \\
(\mathbf{m m})\end{array}$ & $\begin{array}{c}\text { Weight } \\
\text { retained } \\
(\mathbf{g m})\end{array}$ & $\begin{array}{c}\text { Percentage } \\
\text { weight } \\
\text { retained }\end{array}$ & $\begin{array}{c}\text { Cumulative } \\
\text { percentage } \\
\text { weight } \\
\text { retained }\end{array}$ & \multicolumn{2}{|c|}{ Cumulative percent passing } \\
\hline 1 & 10 & 16 & 0.32 & 0.32 & $\mathbf{1 0} \mathbf{~ m m}$ & $\begin{array}{c}\text { IS 383 } \\
\mathbf{( 1 9 7 0 )} \text { limits }\end{array}$ \\
\hline 2 & 4.75 & 4546 & 90.92 & 91.24 & 8.76 & $85-100$ \\
\hline 3 & 2.36 & 318 & 6.36 & 97.6 & 2.4 & $0-20$ \\
\hline
\end{tabular}

Table 3 Sieve analysis of $10 \mathrm{~mm}$ Coarse aggregate

\begin{tabular}{|c|c|c|c|c|c|c|}
\hline \multirow[b]{2}{*}{ S.No } & \multirow[b]{2}{*}{$\begin{array}{l}\text { Sieve size } \\
\quad(\mathbf{m m})\end{array}$} & \multirow[b]{2}{*}{$\begin{array}{c}\text { Weight } \\
\text { retained } \\
(\mathrm{gm})\end{array}$} & \multirow[b]{2}{*}{$\begin{array}{l}\text { Percentage } \\
\text { weight } \\
\text { retained }\end{array}$} & \multirow{2}{*}{$\begin{array}{c}\text { Cumulative } \\
\text { percentage } \\
\text { weight } \\
\text { retained }\end{array}$} & \multicolumn{2}{|c|}{ Cumulative percent passing } \\
\hline & & & & & $10 \mathrm{~mm}$ & $\begin{array}{c}\text { IS } 383 \\
\text { (1970) limits }\end{array}$ \\
\hline 1 & 10 & 16 & 0.32 & 0.32 & 99.68 & $85-100$ \\
\hline 2 & 4.75 & 4546 & 90.92 & 91.24 & 8.76 & $0-20$ \\
\hline 3 & 2.36 & 318 & 6.36 & 97.6 & 2.4 & $0-5$ \\
\hline
\end{tabular}

\subsubsection{Fine Aggregate}

The sand used throughout the experimental work was obtained from the river Swarnamukhi near chandragiri in chittoor district. The bulk specific gravity in oven dry condition and water absorption of the sand as per IS code were 2.62 and $1 \%$ respectively $^{8}$. The gradation of the sand was determined by sieve analysis as per IS code and presented in the Table $4^{9}$. 
Strength Properties of Bagasse Ash and GGBS Based Geo-polymer Concrete

Table 4 Sieve analysis of Fine Aggregate (Sand)

\begin{tabular}{|c|c|c|c|c|c|c|}
\hline \multirow[b]{2}{*}{ S.No } & \multirow[b]{2}{*}{ Sieve No/ size } & \multirow[b]{2}{*}{$\begin{array}{l}\text { Weight } \\
\text { retained } \\
\quad(\mathrm{gm})\end{array}$} & \multirow[b]{2}{*}{$\begin{array}{l}\text { Percentage } \\
\text { weight } \\
\text { retained }\end{array}$} & \multirow{2}{*}{$\begin{array}{l}\text { Cumulative } \\
\text { percentage } \\
\text { weight } \\
\text { retained }\end{array}$} & \multicolumn{2}{|c|}{ Cumulative percent passing } \\
\hline & & & & & $\begin{array}{c}\text { Fine } \\
\text { aggregate }\end{array}$ & $\begin{array}{c}\text { IS } 383(1970)- \\
\text { Zone II } \\
\text { requirement }\end{array}$ \\
\hline 1 & $3 / 8 "(10 \mathrm{~mm})$ & 0 & 0 & 0 & 100 & 100 \\
\hline 2 & No.4 $(4.75 \mathrm{~mm})$ & 12 & 1.2 & 1.2 & 98.8 & $90-100$ \\
\hline 3 & No.8 (2.36mm) & 35 & 3.5 & 4.7 & 95.3 & $75-100$ \\
\hline 4 & No.16 (1.18mm) & 135 & 13.5 & 18.2 & 81.8 & $55-90$ \\
\hline 5 & No. $30(600 \mu \mathrm{m})$ & 366 & 36.6 & 54.8 & 45.2 & $35-59$ \\
\hline 6 & No. $50(300 \mu \mathrm{m})$ & 290 & 29.0 & 83.8 & 16.2 & $8-30$ \\
\hline 7 & No.100 $(150 \mu \mathrm{m})$ & 132 & 13.2 & 97.0 & 3.0 & $0-10$ \\
\hline
\end{tabular}

\subsubsection{Mixture Proportions}

Based on the limited past research on GPC (Hardjito \& Rangan, 2005) ${ }^{10}$, the following proportions were selected for the constituents of the mixtures. The following scenario describes the GPC mix design of the present study: Assume that normal-density aggregates in SSD (Saturated surface Dry) condition are to be used and the unit-weight of concrete is 2400 $\mathrm{kg} / \mathrm{m}^{3}$. In this study, take the mass of combined aggregates as $77 \%$ of the total mass of concrete, i.e. $0.77 \times 2400=1848 \mathrm{~kg} / \mathrm{m}^{3}$. The coarse and fine (combined) aggregates may be selected to match the standard grading curves used in the design of Portland cement concrete mixtures. For instance, the coarse aggregates (70\%) may comprise $776 \mathrm{~kg} / \mathrm{m}^{3}(60 \%)$ of 20 mm aggregates, $518 \mathrm{~kg} / \mathrm{m}^{3}(40 \%)$ of $10 \mathrm{~mm}$ aggregates, and $554 \mathrm{~kg} / \mathrm{m}^{3}$ (30\%) of fine aggregate to meet the requirements of standard grading curves. The adjusted values of coarse and fine aggregates are $774 \mathrm{~kg} / \mathrm{m}^{3}$ of $20 \mathrm{~mm}$ aggregates, $516 \mathrm{~kg} / \mathrm{m}^{3}$ of $10 \mathrm{~mm}$ aggregates and $549 \mathrm{~kg} / \mathrm{m}^{3}(30 \%)$ of fine aggregate, after considering the water absorption values of coarse and fine aggregates. The mass of geo polymer binders (Bagasse ash and GGBS) and the alkaline liquid $=2400-1848=552 \mathrm{~kg} / \mathrm{m}^{3}$. Take the alkaline liquid-to-Bagasse ash + GGBS ratio by mass as 0.35; the mass of Bagasse ash + GGBS $=552 /(1+0.35)=409$ $\mathrm{kg} / \mathrm{m}^{3}$ and the mass of alkaline liquid $=552-409=143 \mathrm{~kg} / \mathrm{m}^{3}$. Take the ratio of sodium silicate $\left(\mathrm{Na}_{2} \mathrm{SiO}_{3}\right)$ solution-to-sodium hydroxide $(\mathrm{NaOH})$ solution by mass as 2.5 ; the mass of sodium hydroxide $(\mathrm{NaOH})$ solution $=144 /(1+2.5)=41 \mathrm{~kg} / \mathrm{m}^{3}$; the mass of sodium silicate solution $=143-41=102 \mathrm{~kg} / \mathrm{m}^{3}$. The sodium hydroxide solid $(\mathrm{NaOH})$ is mixed with water to make a solution with a concentration of 8 Molar. This solution comprises $40 \%$ of $\mathrm{NaOH}$ solids and $60 \%$ water, by mass. For the trial mixture, water-to-geopolymer solids ratio by mass is calculated as follows: In sodium silicate solution, water $=0.559 \times 102=57 \mathrm{~kg}$, and solids $=102-57=45 \mathrm{kgs}$. In sodium hydroxide solution, solids $=0.40 \mathrm{x} 41=16 \mathrm{~kg}$, and water $=41-16=25 \mathrm{~kg}$. Therefore, total mass of water $=57+25=82 \mathrm{~kg}$, and the mass of geopolymer solids $=409$ (i.e. mass of Bagasse ash and GGBS) $+45+16=470 \mathrm{~kg}$. Hence, the water-to-geopolymer solids ratio by mass $=82 / 470=0.17$. Extra water is calculated and added on trial for adequate workability. 
Table 5 GPC Mix Proportions

\begin{tabular}{|c|c|c|c|c|}
\hline \multirow{2}{*}{ Materials } & & & Mass $\left(\mathrm{kg} / \mathrm{m}^{3}\right)$ & \\
\hline & & BA50-GGBS50 & BA75-GGBS25 & BA100-GGBS0 \\
\hline \multirow{2}{*}{ Coarse aggregate } & $20 \mathrm{~mm}$ & 774 & 774 & 774 \\
\hline & $10 \mathrm{~mm}$ & 516 & 516 & 516 \\
\hline Fine aggregate & Sand & 549 & 549 & 549 \\
\hline Bagasseash & & 204.5 & 306.75 & 409 \\
\hline GGBS & & 204.5 & 102.25 & 0 \\
\hline Sodium silicate solution & & 102 & 102 & 102 \\
\hline \multicolumn{2}{|c|}{ Sodium hydroxide solution } & $41(10 \mathrm{M})$ & $41(10 \mathrm{M})$ & $41(10 \mathrm{M})$ \\
\hline Extra water & & 55 & 65 & 75 \\
\hline \multicolumn{2}{|c|}{$\begin{array}{l}\text { Alkaline solution/ (BA+GGBS) } \\
\text { (by weight) }\end{array}$} & 0.35 & 0.35 & 0.35 \\
\hline \multicolumn{2}{|l|}{$\begin{array}{l}\text { Water/ geopolymer solids } \\
\text { (by weight) }\end{array}$} & 0.29 & 0.29 & 0.29 \\
\hline
\end{tabular}

\section{RESULTS AND DISCUSSIONS}

\subsection{Compressive Strength}

Table 6. Shows the compressive strength of GPC mixes with different proportions of Bagasseash and GGBS (BA50-GGBS50; BA25-GGBS75; BA0-GGBS100) at different curing periods.

Table 6 Compressive strength of GPC

\begin{tabular}{|c|c|c|c|c|}
\hline \multirow{2}{*}{$\begin{array}{c}\text { Mechanical } \\
\text { property }\end{array}$} & \multirow{2}{*}{$\begin{array}{c}\text { Age } \\
\text { (in } \\
\text { days) }\end{array}$} & $\begin{array}{c}\text { BA50- } \\
\text { GGBS50 }\end{array}$ & $\begin{array}{c}\text { BA75- } \\
\text { GGBS25 }\end{array}$ & BA100-GGBS0 \\
\hline \multirow{3}{*}{$\begin{array}{c}\text { Compressive } \\
\text { strength, } f^{\prime}\end{array}$} & 7 & 40 & 21.3 & 10.1 \\
\cline { 2 - 5 }$(\mathrm{MPa})$ & 14 & 46.5 & 30.5 & 18.2 \\
\cline { 2 - 5 } & 28 & 53.5 & 35.4 & 24.5 \\
\cline { 2 - 5 } & 56 & 63 & 49 & 38 \\
\cline { 2 - 5 } & 112 & 65 & 52 & 41 \\
\hline
\end{tabular}

It was observed that there was a significant decrease in compressive strength with the increase in percentage of Bagasseash from $50 \%$ to $100 \%$ in all curing periods as shown in Fig. 1. It can be concluded that the increase in Bagasseash replacement level has significant decrease strength in geopolymers but still exhibits good normal strength. The GPC with 100\% Bagasseash sample exhibited compressive strength values of $10.1 \mathrm{MPa}, 18.2 \mathrm{MPa}, 24.5 \mathrm{MPa}$, $38 \mathrm{MPa}$ and $41 \mathrm{MPa}$ after 7, 14, 28, 56 and 112 days of curing respectively at ambient room temperature.

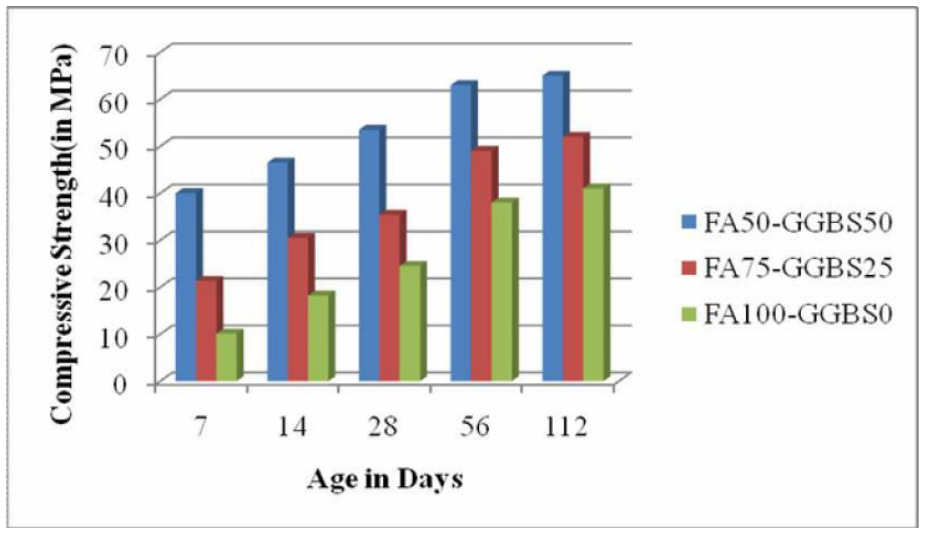

Figure 1 Flexural strength of mixes

https://iaeme.com/Home/journal/IJCIET 107 


\subsection{Split Tensile Strength}

Table 7. Shows the split tensile strength of GPC mixes with different proportions of Bagasseash and GGBS (BA50-GGBS50; BA25-GGBS75; BA0-GGBS100) at different curing periods.

Table 7 Split tensile strength of GPC

\begin{tabular}{|l|c|c|c|c|}
\hline \multirow{2}{*}{$\begin{array}{c}\text { Mechanical } \\
\text { property }\end{array}$} & \multirow{2}{*}{$\begin{array}{c}\text { Age } \\
\text { in days) }\end{array}$} & $\begin{array}{c}\text { MA50- } \\
\text { GGBS50 }\end{array}$ & $\begin{array}{c}\text { BA75- } \\
\text { GGBS25 }\end{array}$ & BA100-GGBS0 \\
\hline $\begin{array}{l}\text { Split tensile } \\
\text { strength, } \mathrm{f}_{\mathrm{ct}}\end{array}$ & 28 & 3.25 & 3.04 & 2.82 \\
\cline { 3 - 5 }$(\mathrm{MPa})$ & 56 & 3.38 & 3.16 & 2.98 \\
\cline { 2 - 5 } & 112 & 3.52 & 3.33 & 3.12 \\
\hline
\end{tabular}

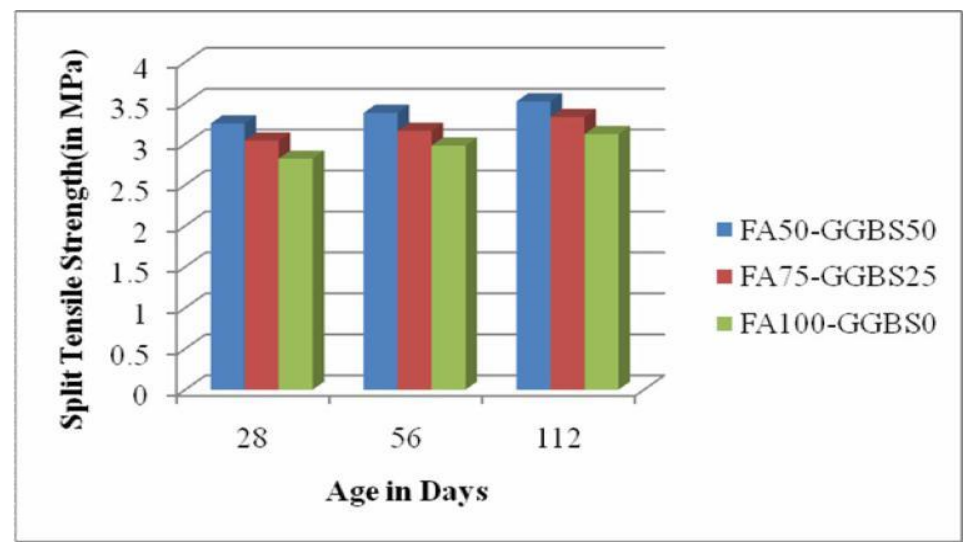

Figure 2 Split tensile strength of mixes

It was observed that there was a significant decrease in splitting tensile strength with the increase in percentage of Bagasseash from $50 \%$ to $100 \%$ in all curing periods as shown in Fig. 2. It can be concluded that the increase in Bagasseash replacement level weakens the microstructure of GPC thus leads to detriment of splitting tensile strength of GPC but the decrement is less.

The GPC with 100\% Bagasseash sample exhibited splitting tensile strength values of 2.82 $\mathrm{MPa}, 2.98 \mathrm{MPa}$ and $3.12 \mathrm{MPa}$ after 28, 56 and 112 days of curing respectively at ambient room temperature.

\subsection{Flexural Strength}

Table 8. Shows the flexural strength of GPC mixes with different proportions of Bagasseash and GGBS (BA50-GGBS50; BA25-GGBS75; BA0-GGBS100) at different curing periods.

Table 8 Flexural strength of GPC

\begin{tabular}{|l|c|c|c|c|}
\hline \multirow{2}{*}{ Mechanical property } & \multirow{2}{*}{$\begin{array}{c}\text { Age } \\
\text { (days) }\end{array}$} & $\begin{array}{c}\text { BA50- } \\
\text { GGBS50 }\end{array}$ & $\begin{array}{c}\text { BA25- } \\
\text { GGBS75 }\end{array}$ & BA0-GGBS100 \\
\hline \multirow{2}{*}{$\begin{array}{l}\text { Flexural strength, } \mathrm{f}_{\mathrm{cr}} \\
(\mathrm{MPa})\end{array}$} & 28 & 5.35 & 5.06 & 4.98 \\
\cline { 2 - 5 } & 56 & 5.92 & 5.36 & 5.14 \\
\cline { 2 - 5 } & 112 & 6.42 & 5.96 & 5.44 \\
\hline
\end{tabular}




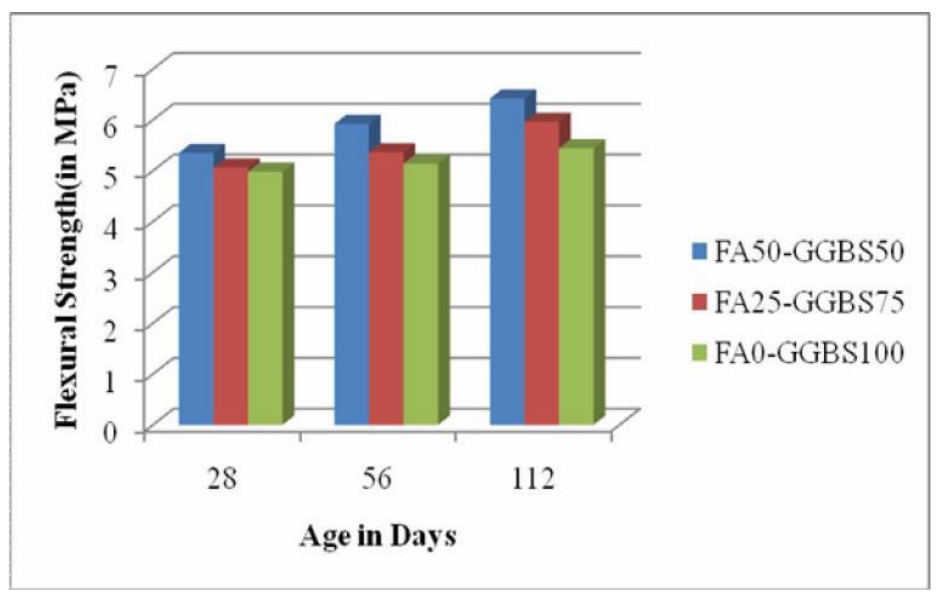

Figure 3 Flexural strength of mixes

It was observed that there was a significant decrease in flexural strength with the increase in percentage of Bagasse ash from $50 \%$ to $100 \%$ in all curing periods as shown in Fig. 3. It can be concluded that the decrease in GGBS replacement level reduce the Silica content of GPC thus lessens the flexural strength of GPC but maintains its strength. The GPC with 100\% Bagasse ash sample exhibited Flexural strength values of $4.98 \mathrm{MPa}, 5.14 \mathrm{MPa}$ and $5.44 \mathrm{MPa}$ after 28, 56 and 112 days of curing respectively at ambient room temperature.

From the results it is revealed that GGBS and BA blended GPC mixes attained enhanced mechanical properties at ambient room temperature curing itself without the need of heat curing as in the case of only BA based GPC mixes Siddique (2007).

\section{CONCLUSIONS}

Based on the test results, the following conclusions are drawn:

- GGBS blended BA based GPC mixes attained enhanced mechanical properties at ambient room temperature curing itself without the need of heat curing as in the case of only BA based GPC mixes.

- Bagasseash based GPC mixes have attained comparable values of mechanical properties at ambient room temperature curing at all ages to normal Strength.

- Keeping in view of savings in natural resources, sustainability, environment, production cost, maintenance cost and all other GPC properties, it can be recommended as an innovative construction material at low cost for the use of constructions.

- Though $100 \%$ Bagasseash exhibited decrease in strength, it maintains the strength. The cost is also low compared to the 50\% GGBS\& 50\% Bagasseash

\section{REFERENCES}

[1] J. Davidovits, “Geopolymers: Man-Made Geosynthesis and the Resulting Development of Very Early High Strength Cement”, J. Materials Education Vol. 16 (2\&3), 1994, pp. 91139.

[2] P. Nath and P.K. Sarker, " Effect of GGBS on setting, workability and early strength properties of Bagasseash geopolymer concrete cured in ambient condition", Construction Building Materials Vol. 66, 2014, pp. 163171

[3] P.K. Sarker, S. Kelly and Z. Yao, "Effect of exposure on cracking, spalling and residual strength of Bagasseash geopolymer concrete", Materials and Design Vol. 63, 2014, pp. 584-592. 
[4] P.S. Deb, P. Nath and P.K. Sarker, "The effects of ground granulated blast-furnace slag blending with Bagasseash and activator content on the workability and strength properties of geopolymer concrete cured at ambient temperature", Materials and Design Vol. 62, 2014, pp. 32-39.

[5] J. Davidovits, "Geopolymers: Inorganic Polymeric New Materials", Journal of Thermal Analysis Vol. 37, 1991, pp.1633-1656.

[6] J. Davidovits, "Global Warming Impact on the Cement and Aggregate Industries", World Resource review, Vol. 6, no. 2, 1994, pp. 263-278.

[7] Palomo, A.; Grutzeck, M.W.; Blanco, M.T. (1999). Alkali-activated Bagasseashes cement for the future. Cement and Concrete Research, 29(8), 1323-1329.

[8] IS 2386 (1963). Methods of test for aggregates for concrete. Part III - Specific gravity, Density, Voids, Absorption and Bulking. Bureau of Indian Standards, New Delhi.

[9] IS 383 (1970). Specification for coarse and fine aggregates from natural sources for concrete. Bureau of Indian Standards, New Delhi.

[10] Hardjito, D., \& Rangan, B. V. (2005). Development and Properties of Low-Calcium BagasseAsh-Based Geopolymer Concrete. Research Report GC1, Perth, Australia: Faculty of Engineering, Curtin University of Technology.

[11] IS 10262 (2009). Concrete Mix Proportioning-Guidelines. Bureau of Indian Standards, New Delhi.

[12] IS 456 (2000). Plain and reinforced concrete code for practice. Bureau of Indian Standards, New Delhi. 